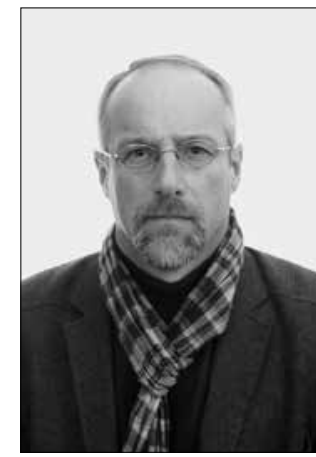

https://doi.org/10.24101/logos.2017.34

\title{
VLADISLAVS MALAHOVSKIS
}

Rėzeknės technologijų akademija, Latvija

Rezekne Academy of Technologies, Latvia

\section{FAKTORIAI, FORMAVĘ RELIGINE (KATALIKIŠKAJA) TAPATYBE: LATGALOS PAVYZDYS ISTORINIAME KONTEKSTE}

\author{
The Factors Forming the Religious (Catholic) Identity: \\ The Example of Latgale in Historical Context
}

\begin{abstract}
SUMMARY
The ethnographic region of eastern Latvia is Latgale. This region has a number of features that differentiate it from the rest of Latvia: 1) the dominance of Catholic faith (as opposed to Lutheranism in the rest of Latvia); 2) the linguistic peculiarities of the Latgallians, and 3) the mixed ethnic composition of the population (the presence of Russian and Polish culture must be noted especially). Latgale historically has had several parallels and points of connection with Lithuania. The aim of the present article is to reveal the peculiarities of the Catholic identity in Latgale from the historical perspective. The article describes the following Catholic identity-related issues: 1) the issue of Counter-Reformation and conversion; 2) the influence of the Catholic Church on cultural and social-political processes; 3) the prevalence of Catholic identity over the ethnic one; 4) the commemorative graveyard meeting.
\end{abstract}

\section{SANTRAUKA}

Rytu Latvijos regionas - Latgala. Šis regionas turi bruožų, kuriais išsiskiria Latvijoje: 1) dominuoja katalikybė (Latvijoje vyrauja liuteronizmas); 2) latgaliečių kalba savita; 3) gyventoju etninė sudètis mišri (ypač minètinos rusų ir lenkų tautinės bendrijos bei jų kultūrų įtaka). Latgala turi istorinių paralelių ir sąsajų su Lietuva. Straipsnio tikslą - atskleisti katalikiškosios tapatybės bruožus istorinèje perspektyvoje - lèmė pasirinktų klausimų turinio apibrēžtis. Straipsnyje analizuojami šie su katalikiškąja tapatybe susiję klausimai: 1) katalikybės atgaivinimas ir religinė konversija; 2) Katalikų Bažnyčios įtaka kultūriniams ir socialiniams politiniams procesams; 3) katalikiškosios tapatybès dominavimas etninès savimonės atžvilgiu; 4) kapinių švenčiu tradicija.

RAKTAŽODŽIAI: Latgala, katalikiškoji tapatybė, katalikybės atgaivinimas, kultūra, etninė savimonė, kapinių šventės. KEY WORDS: Latgale, catholic identity, re-catholization, culture, ethnic identity, remembrance days in cemeteries. 


\section{IVADAS}

Šiais laikais, kai „griūna“ valstybinių, etninių bei informacinių erdvių ribos, tiek visuomenëje, tiek tarp mokslininku kyla susidomejjimas lokaliaisiais (regioniniais) procesais, ju savybėmis ir geneze. Baltijos šalyse yra regionų, turinčiu istoriškai susiklosčiusią ar tebesiformuojančią (pavyzdžiui, dèl globalizacijos bei glokalizacijos procesų) savitą lokalinę tapatybę. Latvijoje toks regionas yra Latgala, Lietuvoje - Žemaitija, Estijoje Idas-Viru sritis. Latgala ir senieji jos gyventojai - Latgalos latviai (latgaliečiai) pirmiausia sietini su keliais regioniniais bruožais: dominuojančia katalikybe (Latvijoje vyrauja liuteronizmas), latgaliečių kalbos savitumu ir mišria gyventoju etnine sudètimi (ypač minètinos rusų ir lenkų tautinès bendrijos bei juc kultūru itaka). Latgala turi istorinių paralelių ir sąsaju su Lietuva. Tyrimo kontekste galima akcentuoti tai, kad (1) Latgala daugiau nei du šimtmečius (1569-1772) priklausè Abiejų Tautų Respublikai (iš pradžių (1561-1569) - kaip Lietuvos Didžiosios Kunigaikštystès provincija); (2) po eilinio lenkų patriotu 1863-1864 m. sukilimo prieš Rusijos imperijos režimą katalikai buvo laikomi nelojaliais valstybei. Lietuvos ir Latgalos teritorijose kaip viena iš represinių sankcijų buvo įdiegtas spaudos lotyniškais rašmenimis draudimas, kuris buvo atšauktas tik 1904 m. Tai smarkiai sulètino nacionalinès kultūros plètojimąsi.

Kalbant apie religinès (katalikiškosios) tapatybės bruožus reikia pažymèti, jog tapatybė yra labai sudètingas konceptas. Tapatybę galima apibūdinti kaip individo pasirinkimo ir vertybių sąveiką su ivvairiomis socialinemis įtakomis ir struktūromis. Šiuolaikiniam pasauliui būdinga tapatybių ivvairovè, kaita ir tarpusavio konkurencija ${ }^{1}$. Apžvelgiant religinę tapatybę formuojančius faktorius, pravartu pasiremti Jeremy Gunno religinès išraiškos aspektų tipologija: religija kaip tikèjimas (remiasi žmogaus įsitikinimais), religija kaip tapatybė (susijusi su priklausymu tam tikrai grupei) ir religija kaip gyvenimo būdas (konkrečios tradicijos, papročiai, ritualai) ${ }^{2}$. Religija kaip tapatybè - gebejjimas atpažinti savyje tikejjimo faktorių - labiau siejasi su priklausymu kuriai nors konkrečiai religinei tradicijai. Remiantis šiuo aspektu, priklausymą kuriai nors religijai ar konfesijai dažniausiai nulemia aplinka, kurioje žmogus gimsta. Jei šeimos tèvai yra katalikai, tai ir jų vaikai greičiausiai bus katalikai. Kalbant apie katalikiškają tapatybę galima paminèti toki ritualą kaip mažų vaikų krikštas. Krikšto ritualu ittvirtinamas vaiko priklausymas šiai konfesijai. Kitas žingsnis, kuriuo sustiprinama katalikiškoji tapatybė, yra Pirmosios Komunijos sakramento prièmimas vaikystëje.

2006-2009 m. Latgaloje buvo vykdytas didelès apimties projektas „Latgalos etnolingvistinès situacijos tyrimas". Ji atliko Milano universiteto Europos lingvistinių studijų centro ir Rėzeknės technologiju akademijos (tuomet - Rèzeknès aukštosios mokyklos) mokslininkai. Projekto metu buvo apklausta 9076 respondentai (t. y. 3 proc. Latgalos gyventoju). Apklausos apie savęs priskyrimą kuriai nors religinei konfesijai rezultatai atskleidè, jog dauguma, 69,2 proc., apklaustuju sudarè katalikai, 15,2 proc. - stačiatikiai, 
8,0 proc. - sentikiai, 7,2 proc. - liuteronai, 0,1 proc. - judejai, o 0,3 proc. save priskyrẻ kitoms religijoms ar konfesijoms. 82,4 proc. projekto respondentu atsakè, jog religine praktika (malda) užsiima ir namuose ${ }^{3}$. Minètieji apklausos duomenys liudija, jog ir šiais laikais religinis faktorius visuomeneje yra reikšmingas.

Straipsnio tikslą - atskleisti katalikiškosios tapatybės Latgaloje bruožus isto- rinejje perspektyvoje - lèmè pasirinktų klausimų turinio apibrezžtis. Straipsnyje analizuojami šie su Latgalos katalikiškąja tapatybe susiję klausimai: 1) katalikybės atgaivinimas ir religinè konversija; 2) Katalikų Bažnyčios įtaka kultūriniams ir socialiniams politiniams procesams; 3) katalikiškosios tapatybès dominavimas etninès savimonès atžvilgiu; 4) kapinių švenčių tradicija.

\section{KATALIKYBĖS ATGAIVINIMO IR KONVERSIJOS KLAUSIMAS}

Pasirašius Altmarko taikos sutarti (1629), Latgala liko Lietuvos-Lenkijos valstybès sudètyje. Latgalos dvarininkiją sudare buvę Livonijos ordino pareigūnai bei Abiejų Tautų Respublikos valstybès kilmingieji. Latgala buvo išdalinta maždaug 60-čiai dvarininkų šeimų. Vokiečių ir lietuvių kilmės dvarininkija ilgainiui sulenkejo. Trūksta istorinių šaltinių, galinčiu padèti atsakyti i klausima, kaip lenkams pavyko nutautinti kilmingų vokiečių kryžiuočiu giminių palikuonis. Vèlesnèms kartoms tik dvarininku pavardès tebepriminè jų tikraają kilmę: Manteifeliai, Borchai, Pliateriai, Hilzenai ${ }^{4}$ ir kt.

Katalikybės atgaivinimo klausimą pirmiausia reikia aptarti nuo Latgalos dvarininku perejjimo ị Romos kataliku tikèjimą. XVII a. viduryje Latgaloje buvo daugiau nei 30 dvarininkų šeimų, priklausiusiu protestantams ${ }^{5}$, kuriu dauguma išpažino liuteronų tikèjimą. Reikia pabrèžti, kad dẻl istorinių šaltinių trūkumo nėra žinoma, kiek liuteronybė buvo paplitusi tarp Latgalos valstiečių. Paprastai valstiečiai buvo priskiriami savo dvarininkų konfesijai. Nuo XVII a. pabaigos iki Latgalos prijungimo prie Rusijos imperijos (1772) i katalikybę perëjo beveik visi dvarininkai liuteronai. XVIII a. gale liuteronizmo itaka Latgaloje tiek sumažèjo, kad regione funkcionavo tik viena liuteroniška parapija 6 .

Kas lèmè šią konversiją? Yra tyrinètojų, manančiu, jog ",atsiversti“ paskatino savanaudiški materialiniai sumetimai ir karjeros galimybès arba „dailiosios lenkų nuotakos", kai konfesinė priklausomybe buvo keičiama tuokiantis su moterimi katalike ${ }^{7}$. Be abejonès, perèjimas i katalikybę atvėrè platesnes karjeros galimybes, nes jos liuteronų tikejjimą išpažistančio aristokrato katalikiškoje Abiejų Tautų Respublikoje buvo suvaržytos. Tačiau apžvelgiant konversijos motyvus negalima apsiriboti tik viena jų rūšimi. Archyvinèje jèzuitų ordino medžiagoje randama žinių, kad konversija vyko ir dèl kitu priežasčių. Pavyzdžiui, $1721 \mathrm{~m}$. Dinaburge (Daugpilyje) $i$ kataliku tikejjimą po trejus metus trukusių teologinio pobūdžio svarstymu perèjo du Lenkijos karališkosios armijos karininkai. 1708 m. dvi kilmingos Kuršo matronos ị katalikų tikejjimą perëjo pa- 
veiktos Kraslavos bažnyčios šventuju paveikslų. Ne kartą minimi „atsivertimai" ligos mirties patale ${ }^{8}$.

Itaką konversijai darè ir jèzuitų ordinas. Latgala priklausè Lietuvos jèzuitų provincijai, kuri XVII a. pradžioje buvo atsiskyrusi nuo Lenkijos provincijos, o jos centras nuo $1629 \mathrm{~m}$. buvo Dinaburge? Jèzuitai steigè savo misijas įvairiose Latgalos vietose. Ordinui priklause ne tik lietuvių ar lenkų kilmės broliai, bet ir vienuoliai iš Vokietijos, Ispanijos, Prancūzijos ir kt. ${ }^{10}$ Norèdami, kad misijos vyktų sẻkmingai, jie visi išmoko vietinę latvių (latgaliečių) kalbą.

Dinaburgo jèzuitu archyvo ataskaitose galima apčiuopti katalikybės atgaivinimo veiklos specifiką - viena svarbiausių priemonių buvo švietimas. XVII a. viduryje Dinaburgo rezidencijoje puse jėzuitų buvo mokytojai, o XVIII a. pastebimas ir profesūros atsiradimas ${ }^{11}$. Jèzuitu isteigtose mokyklose nemokamai buvo teikiamas aukštos kokybès išsilavinimas ne tik katalikų, bet ir kitų krikščioniškų konfesijų vaikams ${ }^{12}$. Visai tikètina, jog šių mokyklų mokymo turinys ir auklejjimo metodai turejjo įtakos moksleivių perëjimui i katalikų tikèjimą. Jèzuitu veikla padejjo katalikybei įsitvirtin- ti ne tik tarp aristokratijos, bet ir plačiuose valstietijos sluoksniuose. Tai, kad kovą su pagonybe bei jèzuitú pastangas atgaivinti katalikybę lydèjo sèkmè bei liaudies palaikymas, lèmė keli faktoriai: 1) valdanti dvarininkija (šlèktos) nesirūpino gyventojų kultūriniais ir kt. poreikiais. Tarp jų ir vietinių gyventojų egzistavo socialiniai, o tarp lietuvių ir lenku kilmès kunigu - ir kalbiniai barjerai. Tuo tarpu su jèzuitais šių problemų nebuvo. Jèzuitai pasižymèjo kuklumu, tačiau svarbiausia - išmoko ir vartojo vietinę kalbą. Pasitelkę pamokslus ir latgaliečių kalba parašytas knygas, jèzuitai igavo žmonių pasitikejjimą; 2) jèzuitai rengè viešus disputus su protestantais, kuriuose dažniausiai ir nugalèdavo, nes buvo labai gerai išsilavinę, mokèjo logiškai argumentuoti. Disputuose klausytoju teisemis dalyvaudavo ir vietiniai gyventojai. Tai skatino ugdyti mąstymą ir polemikos kultūrą ${ }^{13}$; 3) jèzuitai aktyviai kovojo su senujuc mitologinių dievų garbinimu, tačiau ju veikla neapsiribojo tik krikščioniškojo tikejjimo skelbimu. Populiarindami žinias apie racionalų žemès dirbima, naujų kultūrų auginima, darbo įrankių tobulinimą jèzuitai rūpinosi ir kelti ūkinę gerovę.

\section{KATALIKŲ BAŽNYČIOS ITAKA KULTÜRINIAMS IR SOCIALINIAMS POLITINIAMS PROCESAMS}

Kalbant apie Katalikų Bažnyčios įtaką Latgalos kultūros procesams reikia akcentuoti ir jèzuitų veiklos produktyvumą. Reikšmingas laimëjimas buvo latgaliečių kalbos rašybos ittvirtinimas. Latgaliečių rašytinès kalbos pagrindu yra laikoma „Evangelia Toto Anno“ („Evangelijos vi- siems metams“), išleista Vilniuje (1753). Ji laikoma pirmąja latgalietiškai parašyta ir išspausdinta knyga, pasiekusia mūsų laikus. 2004 m. švenčiant „Evangelia Toto Anno" išleidimo 250-ąsias (2003) ir spaudos draudimo atšaukimo 100-ąsias metines $(2004)^{14}$, buvo išleistas faksimili- 
nis šio vertimo leidimas su tekstų vertimu į lenkų ir lotynų kalbas.

Sakralinè architektūra ir vaizduojamasis menas Latgaloje suklestejo vienuolių dominikonų ordino dèka. Dominikonų vienuoliai savo veiklą Latgaloje pradèjo $1694 \mathrm{~m}$. Tais pačiais metais jie ịkūrè vienuolyną Pasienëje, o 1699 m. - Agluonoje $^{15}$. Iš šių vietų buvo koordinuojamas ir kitu misiju punktu steigimas visoje Latgaloje. Kitaip nei jèzuitai, dominikonai nekreipé dèmesio ì nacionalini aspektą, mažai paisè vietinių tradicijų, lenkų kalbą vartojo ir bažnyčios gyveni$\mathrm{me}^{16}$. Jèzuitu ir dominikonu vienuoliu veiklos dèka Latgaloje iškilo puikūs baroko stiliaus sakralinès architektūros pastatai (Agluonoje, Kraslavoje, Pasienèje ir kt.). Ypač išsiskiria vẻlyvojo baroko stiliaus architektūros pavyzdys - Agluonos bažnyčia. Vietinių dvarininkų padedami ją pastate iš Vilniaus atvykę dominikonai. Bažnyčioje dominikonai pakabino Dievo Motinos paveikslą, kuris buvo nutapytas pagal Traku (Lietuva) Dievo Motinos paveikslo pavyzdi. Kiekvienais metais rugpjūčio $15 \mathrm{~d}$. Agluonoje švenčiamos tradicinès Švč. Mergelès Marijos Dangun ėmimo iškilmès, į kurias atvyksta piligrimu minios. Agluonos maldos namai yra vienintelè bažnyčia Latvijoje, kuriai 1980 m. Vatikanas yra suteikęs bazilikos (basilica minoris) statusą o Latvijos valstybé - Kultūros paminklo ir Tarptautinės reikšmės šventovès statusą (1995). 1993 m. rugsèji, vizito i Latviją metu, Agluoną aplankè popiežius Jonas Paulius II.

Kartu su jèzuitu ir dominikonu aktyvia veikla sakralinès dailès srityje po Latgalą plito to meto Europos meno sti- liai, ypač iš Italijos, Abiejų Tautų Respublikos ir Prancūzijos ${ }^{17}$. Reikia pabrěžti, kad minètas religines ir kultūrines veiklas Latgaloje XVII a. ir XVIII a. vykdè palyginti nedidelis skaičius katalikų dvasinių ordinų narių. Prieš Latgalai patenkant į Rusijos imperijos sudètį (1772), čia darbavosi 32 jèzuitai, 36 dominikonai, 2 bernardinai. Dvasininkų buvo ne daugiau kaip 100. Iš 150000 Latgalos gyventojų kataliku parapijoms priklausè apie 100000 kataliku (67 proc.) $)^{18}$. Kitu gyventojų daugumą sudarè žydai ir sentikiai.

Carinès Rusijos imperijos laikotarpiu Latgala priklausė Vitebsko (Lifliandijos) gubernijai (nuo $1802 \mathrm{~m}$.). Carinès rusifikacijos politika uždraudė katalikų dvasinių organų veiklą. XX a. pradžioje, plintant latgaliečiu tautinio atgimimo idèjoms, aktyvią veiklą pradejjo pirmieji latviu kilmès kunigai - Sankt Peterburgo kataliku dvasinès seminarijos absolventai. Būdami arčiau tautos, jie aktyviai veikè ne tik dvasineje ir kultūrineje srityje, bet îsitraukè ir i ùkio reikalus bei politiką. Ypač reikšmingi dvasininkų Nikodemo Rancano (Nikodems Rancāns) ir Francio Trasuno (Francis Trasuns) nuopelnai. $X X$ a. pr. Latgaloje N. Rancanas buvo vienas pirmuju valstiečiu kooperacijos skatintojų ir propaguotojų. $1917 \mathrm{~m}$. balandžio 26-27 d. (pagal seną kalendorių) F. Trasuno iniciatyva Rėzeknèje buvo sušauktas pirmasis Latgalos kongresas, kuriame buvo priimta rezoliucija dèl Latgalos susijungimo su kitais Latvijos regionais ${ }^{19}$.

Susikūrus nepriklausomai Latvijos valstybei (1918-1940), Katalikų Bažnyčia patyré kelias permainas: 1) Kataliku Bažnyčioje vyskupais buvo îšventinti 
latvių kilmės dvasininkai (anksčiau dominavo lenkų ir lietuvių kilmės dvasininkai); 2) $1918 \mathrm{~m}$. rugsèji buvo atkurta Rygos vyskupija (nuo 1923 m. arkivyskupija), kurios administracinès sienos buvo suderintos su Latvijos valstybinèmis sienomis. Rygos vyskupijai buvo priskirti ne tik Latgalos, bet ir Kuršo bei Žiemgalos katalikai.

Taigi susiklosčius naujai situacijai, katalikiškosios tapatybès savimonė buvo stiprinama per dominuojančią Bažnyčios itaką Latgalos kataliku visuomeninei minčiai ir politiniams procesams. Itakingiausios latgaliečiu politinės partijos Latgalos krikščioniškosios valstiečių sąjungos - lyderiai buvo katalikų kunigai. Partija leido ir populiariausią bei didžiausią tiražą Latgaloje turintị laikrašti „Latgolas Vōrds“. Katalikų kunigo pamokslai Latgalos katalikams darẻ daug didesni įspūdì, nei pasaulietinè politinè propaganda. Latgalos istorijos tyrinètojas išeivijoje Mikelis Bukšas (Miķelis Bukšs) rašė, kad dvasininkai, be savo partijos de facto, kiekvienoje parapijoje turëjo "partijos skyrius", kurie buvo arčiau liaudies - tai padejjo skleisti informacija, buvo lengviau daryti itaką žmonėms ${ }^{20}$. Kataliku prievole išpažinti nuodèmes kunigui neretai sukeldavo prieš- taringų emocijų, ypač, jei dvasininkas būdavo politinis oponentas.

Latvijos valstybëje pratęsta ir jèzuitu pradèto katalikiško švietimo tradicija. 1921 m. Agluonoje ėmẻ veikti katalikiška berniuku gimnazija. Greta jos, kaip griežtai katalikiška mokykla, $1928 \mathrm{~m}$. buvo ikurta Jaunagluonos moteru gimnazija. Abieju gimnazijų direktoriais dirbo katalikų dvasininkai. Abi gimnazijos sėkmingai veikè iki Antrojo pasaulinio karo.

Katalikų tikinčiuosius Bažnyčia bandė apsaugoti nuo kitu ittakų. Bet kokie protestantu bandymai Latgaloje vykdyti misijas buvo sustabdyti. Ypač buvo kovojama su latgaliečių kalba protestantų leidžiamomis evangelijomis. Evangelijas latgalietiškai leido ir $1804 \mathrm{~m}$. Londone ikurtos Britu ir užsienio Biblijos draugijos $(B U B D)$ atstovybe Latvijoje. $1924 \mathrm{~m}$. BUBD atstovybẻ latgalietiškai išleido keturias evangelijas. Nors prie evangeliju vertimo dirbo ir katalikas latgaliečiu kultūros veikejjas Eduardas Kozlovskis (Eduards Kozlovskis), ju platinimas sukèlè konfliktus su kataliku dvasininkais, nesutikusiais pripažinti BUBD Biblijos vertimu $u^{21}$. Šios evangelijos 1936 m. latgalietiškų knygų bibliografinėse rodyklèse buvo priskirtos prie sektantu dvasinès literatūros leidiniự ${ }^{22}$.

\section{KATALIKIŠKOS TAPATYBĖS DOMINAVIMAS ETNINĖS SAVIMONĖS ATŽVILGIU}

Po 1863-1864 m. sukilimo prieš carinès Rusijos viešpatavimą latgaliečiams, kuriuos, kaip ir lenkus, rusai laikè katalikais, Rusijos valdžios institucijos uždraudè užimti postus valstybès tarnyboje. Buvo draudžiama statyti naujas kata- likiškas bažnyčias. Latgalos kataliku vaikai neturejjo motyvacijos siekti mokslo, nes jiems, kaip katalikams, bet koks inteligento darbas buvo nepasiekiamas. Vienintele išeitis buvo rinktis dvasininko kelia, nors ir tam reikejjo ypatingo gu- 
bernatoriaus leidimo. Latgalos valstietis katalikas negalèjo įsigyti nekilnojamojo turto. Žemès pirkimo leidimai buvo išduodami itin retai - tik tuomet, kai vietinè policija ar žandarmerija surinkdavo išsamią informaciją apie tai, ar žemès pirkejjas yra politiškai patikimas ir ar nèra nusiteikęs prolenkiškai ${ }^{23}$. Šią nepalankią situaciją buvo galima „ištaisyti“, pavyzdžiui, perejus į stačiatikybę. Tačiau tokia politika Latgaloje nepasiteisino. Gretimai esančioje Vidžemès gubernijoje XIX a. penktajame dešimtmetyje vyko masinė konversija i stačiatikybę. Tarp valstiečiu sklido kalbos, kad tie Baltijos gubernijų valstiečiai, kurie pereis i stačiatikybę, gaus žemės, bus atleisti nuo karinès tarnybos ir mokesčiu. 1845-1852 m. laikotarpiu Vidžemèje apie 113 000, arba 12 proc., visų liuteroniškų parapijų narių perèjo i stačiatikybę ${ }^{24}$. Tačiau ju viltys, sietos su Rusijos vadovybės žadamomis privilegijomis, nepasiteisino. Persivertèliai buvo nusivylę ir norèjo grižti prie liuteronų tikèjimo, tačiau tai nebuvo imanoma, nes, remiantis Rusijos baudžiamuoju kodeksu, kiekvienam, kuris susigundys atsimesti nuo stačiatikybès, grèsè tremtis i Sibirą ${ }^{25}$.

Stiprią latgaliečiu katalikiškosios tapatybès savimonę aktyvino, o iš esmès net apibrèžè, gyvenimas Latgaloje šalia kitų tautu, ypač lenku, rusų ir žydų. Latgaliečiai patyrè kiekvienos iš ju poveikị. Gyvendami tarp kitataučiu, jie buvo priversti prisitaikyti prie ju itakos tiek kultūros, tiek ūkio srityse. Vitebsko gubernijoje latgaliečiai sudarè apie 18 proc. gyventojư ${ }^{26}$. Jie buvo tarsi tautinè mažuma tarp kitų tautinių mažumų. Latgalietiškai savimonei plètotis labiausiai truk- dè ekonominè ir administraciné priklausomybė nuo lenkų dvarininku, o vèliau ir rusų pareigūnų, nes šios tautos - rusai, lenkai ir žydai - Latgaloje turëjo aukštesni socialini ir materialini statusą nei vietiniai valstiečiai. Latgalos tyrinètojas pedagogas Otto Svennè rašè: „Šios aplinkybės sukèlè vietinių latvių (latgaliečių. - V. M.) nevisavertiškumo kompleksą, savineiga, savinieka.." ${ }^{27}$ Negalima O. Svennei pritarti dèl savineigos, nes latgaliečiai sugebejjo išlaikyti savo kalbą ir kultūrą, tiesa, nors ir su kitų kultūrų elementu priemaišomis. Tačiau tam tikras nepasitikejjimas savo jejgomis ir neretai gèda dèl savo kilmès latgaliečiams tikrai buvo būdingas.

Dèl ilgalaikès polonizacijos ir rusifikacijos net nepriklausomos Latvijos valstybės gyvavimo laikotarpiu (1918-1940) Latgalos kaimuose konfesinė (katalikiškoji) tapatybė neretai buvo svarbesnè už nacionalinę (latviškają). $1921 \mathrm{~m}$. Latvijos parlamento pavasarinès sesijos metu, svarstant konkordato su Vatikanu klausimą dèl katalikiškosios Latgalos, buvo akcentuota:

Latgaloje, kur 60 proc. gyventoju sudaro katalikai, gyventojai nesuvokia savo tautybès ir i klausima, kokiai tautybei save priskiria - atsako, kad esą katalikai. Kai jiems paaiškinama, kad katalikybė yra ne tautybè, o tikejjimas, jie sakosi esą lenkai. ${ }^{28}$

Taip pat ir Latgalos politinis veikèjas Francis Kempas (Francis Kemps) XX a. ketvirtajame dešimtmetyje rašè: „Latgalos valstiečiai turëjo ir vis dar išlaiko tokią stiprią religinę savimonę, kad ji nustelbia nacionalinę." ${ }^{29}$ Sąvokos „latgalietis" ir "katalikas" Latgaloje daugeliu atveju yra suprantamos kaip sinonimai. 


\section{KAPINIŲ ŠVENČIŲ TRADICIJA}

Reikšmingas katalikišką tapatybę stiprinantis veiksnys, ypač šiais laikais, susijęs su iš protestantų (liuteronų) perimta kapinių švenčių (latv. kapu svētki) tradicija. Šis apeiginis renginys vyksta kapinėse ir skirtas mirusiems paminè$\mathrm{ti}^{30}$. Kapinių šventè visose Latvijos katalikų ir liuteronu parapijose vyksta kasmet vasaros sezono metu (nuo birželio pabaigos iki rugsèjo pradžios), kiekvienai parapijai paskirtu laiku. Seniausias rašytinis šios šventès liudijimas yra pasakojimas apie iškilmes, vykusias 1831 m. Krimuldos kapinèse. Šventès pavadinimas ir pati tradicija, tiesa, jau modifikuotos formos, iš liuteroniškosios Vidžemès Latgaloje paplito tik XX a. 3-iajame dešimtmetyje ${ }^{31}$. Ruošiantis kapinių šventėms, daug dèmesio skiriama kapų tvarkymui: „prie kauburèlių dedamos vazos su gèlèmis, žvakès, užpilama naujo smèlio, persodinamos gèlès, apkerpami dekoratyviniai krūmai" 32 . Kapų priežiūros tradicija itraukta ir i Latvijos kultūros kanono skyrių „Liaudies tradicijos"33.

Latgalos kapinių švenčių tradicijai būdingos savitos „neoficialios varžybos“ dèl to, kas kapinių švenčių procesijai i̇rengs gražiausią kryžiaus kelio stotị. Kapinių švenčių tradicijas tvirtina kataliku konfesijoje priimtos ir atliekamos apeigos. Atvykus kunigui, kapinèse įsivyrauja tyla, „išrenkamas žmogus, kuris procesijos priekyje neš kryžių, ir dar keturi vyrai, kurie neš simbolini gedulo kilimèlí. Išklausę Dievo žodi, kapinių šventès dalyviai, vadovaujami kunigo, eina procesijoje aplink kapines, sustodami prie kiekviename kapiniu kampe pastatytų stalų (stočių), ant kurių būna padètas kryžius, žvakès ir gèlès"34. Po trumpu pamaldu susirinkusieji bendrauja, lanko kapus. Apeigas kapinèse pratęsia draugu ir giminių susibūrimas namuose prie vaišių stalo, kartais nedidelès vaišès rengiamos ir šalia kapinių.

Sovietmečiu kapinių švenčių tradiciją bandyta sunaikinti arba bent jau susilpninti. Dalyvaujant oficialios vietinès valdžios ir kultūros darbuotojų atstovams, buvo rengiamos mirusiųju atminimo dienos. Neretai tose pačiose kapinèse per vieną dieną vykdavo du skirtingi renginiai - pirmojoje dienos pusejje su sovietų valdžios atstovais, o po pietų - su kunigu. Kapinès ir kapinių šventès iš esmès buvo savotiškas sovietų ideologijos ir Bažnyčios ,kovos laukas".

Dabar i kapinių šventes paprastai suvažiuoja visi po pasauli išsibarstę giminès atstovai. Kapinių šventès laikomos savotišku kasmetiniu visos giminès sąskrydžiu. Kapinès ir jose vykstančios apeigos nèra vien nostalgiška mirusiuju atminties vieta, o teritorija, kurioje galima susitikti „savus“. Šiais laikais religinis kapinių švenčių aspektas neretai „būna šalutinis dalykas, svarbiausia susitikimas su artimaisiais - latgaliečiui kelionè i kapinių šventę yra tarsi piligrimystè i gimtinę, kad galètų atkurti savo energijos užtaisą" 35 . 


\section{IŠVADOS}

1. Giliai įsišaknijusios katalikiškosios tradicijos ir reikšminga Bažnyčios įtaka viešajai nuomonei Latgaloje istoriškai siejama su tuo, kad kataliku dvasinių ordinu ir dvasininkijos veiklos apèmé ne tik dvasinę sfera, bet dare didelę itaką kultūros ir švietimo procesams, taip pat ūkinio gyvenimo gerinimui. Latviu kilmès kataliku dvasininkai tapo Latgalos latvių nacionalinės savimonès žadintojais. Sprendžiant politinę Latgalos ateitị 1917 m. katalikų dvasininkija vaidino reikšmingą vaidmenį.

2. Priklausomybė tokiai stipriai organizacijai kaip Katalikų Bažnyčia nacionalinès priespaudos ir rusifikacijos politikos sąlygomis (ypač XIX a.) suformavo religinę latgaliečių savimonę. Etninès savimonès trūkumas („,esu latvis") buvo "pakeistas" religinès priklausomybès savimone (,esu katalikas").

3. Esmini vaidmeni Latgalos regioninès ir religinès tapatybès supratimui bei išlaikymui turi dominikonu ikurta Agluonos bažnyčia. Ji tapo ne tik svarbiausiais katalikų maldos namais Latvijoje, bet ir reikšmingu piligrimystès objektu visoje Rytu Europoje.

4. Ypatingą vaidmeni katalikiškosios tapatybės stiprinimui turëjo švietimas. Jèzuitu pradètos katalikiškojo švietimo tradicijos savo renesansą išgyveno nepriklausomoje Latvijoje. Iki Antrojo pasaulinio karo Latgaloje veike dvi katalikiškos gimnazijos. Po Latvijos nepriklausomybès atkūrimo Latgaloje veikia dvi katalikiškos viduriniojo mokslo įstaigos - Rėzeknès katalikiškoji vidurinè mokykla, o prie Agluonos bazilikos Katalikiškoji gimnazija.
5. Latvijos Respublikos laikotarpiu (1918-1940) Katalikų Bažnyčia Latgalą laikè savo misijos lauku. Bet kokie protestantų bandymai aktyvinti savo veiklą Latgaloje buvo stabdomi. Sèkmę lèmè stiprus Bažnyčios vaidmuo formuojant viešąją Latgalos katalikų nuomonę.

6. Nepaisant visuomenès sekuliarizacijos tendenciju, kapinių švenčių tradicija Latgaloje atlieka ypatingą vaidmenị palaikant katalikiškają tapatybę. Daugelis Latgalos žmonių, ieškodami geresnio gyvenimo išsivysčiusiose Europos šalyse, jau yra praradę ryši su gimtaja kalba. Neretai būna, kad žmogus kelerius metus nèra lankęsis pamaldose, tačiau vis tiek jis save tapatina su katalikais: Bet aš juk vis dèlto esu katalikas! Tokiu būdu katalikiškoji tapatybè, net jei žmogus ir nèra praktikuojantis katalikas, šiais laikais tampa savotišku sugrižimu ir jungtimi su kažkuo, kas prarasta. Kapinių šventės esmini vaidmeni vaidina ir stiprinant lokalinị (latgalietišką) tapatumą. Todèl galima pagristai manyti, jog šią tradiciją - ko gero, modifikuotos formos - išlaikys ir būsimosios kartos.

7. Šių laiku globalizacijos sąlygomis palaikydama katalikiškąsias tradicijas visuomenėje Katalikų Bažnyčia susiduria su naujais iššūkiais. Latgalos miestuose, taip pat kai kuriose kaimiškose vietovėse, nuo XX a. 10-ojo dešimtmečio gana aktyviai steigiasi naujos protestantiškosios konfesijos (baptistai, septintosios dienos adventistai, sekmininku parapijos ir kt.) bei kiti religiniai judejimai (Jehovos liudytojai, krišnaitai ir kt.). 


\section{Literatūra ir nuorodos}

${ }^{1}$ Laura Uzule, Vita Zelče, Latviešu kapusvētki: identitātes rituāls. Rīga: Mansards, 2014, p. 19.

2 Jeremy Gunn, The Complexity of Religion and the Definition of "Religion" in International Law. Harvard Human Rights Journal, Vol. 16, 2003, p. 201- 205.

${ }^{3}$ Sanita Lazdina (ed.), Ilga Šuplinska (ed.), Valodas Austrumlatvijā: pētījuma dati un rezultāti. Via Latgalica. Humanitāro zinātnu žurnāla pielikums. Rēzekne: Rēzeknes Augstskola, 2009, p. 8-43.

4 Tadeušs Puisāns, Latgale. Vēsturiskas skices. Toronto, 1988, p. 141.

${ }^{5}$ Inese Poča, Latgale Žečpospoḷitas varā (16. gs. II puse -18. gs. beigas). Rēzekne: Rēzeknes Augstskola, 2009, p. 67

${ }^{6}$ Reinis Norkārkls, Protestanti un austrumu kristieši Latgalē Polijas-Lietuvas valdīšanas laikā, 1582-1772. Cel̦š, 2011, nr. 61, p. 152.

7 Ten pat, p. 160.

${ }^{8}$ Jozefs Kleijntjenss, Latvijas vēstures avoti jezuītu ordeña arhīvos. Rīga: Apgāds Latvju Grāmata 1940, p. 387-388.

9 Pēteris Zeile, Latgales kultūras vēsture. Rēzekne: Latgales Kultūras centra izdevniecība, 2006, p. 190.

10 Ten pat, p. 192.

11 Jozefs Kleijntjenss, Latvijas vēstures avoti jezuītu ordeṇa arhīoos. Rīga: Apgāds Latvju Grāmata, 1941, p. 362.

12 Reinis Norkārkls, Protestanti un austrumu kristieši Latgalē Polijas-Lietuvas valdīšanas laikā, 1582-1772, p. 160.

13 Pēteris Zeile, Latgales kultūras vēsture, p. 193.

14 Ten pat, p. 195.

15 Julians Vaivods, Katoḷ u baznīcas vēsture Latvijā. Rīga: Rīgas Metropolijas kūrija, p. 441.

16 Francis Kemps, Latgales likteņi. Rīga: Avots, 1991, p. 32.
17 Pēteris Zeile, Latgales kultūras vēsture, p. 262.

18 Heinrihs Strods, Latvijas katoḷu baznīcas vēsture (1075-1995). Rīga, 1996, p. 173.

19 Ëriks Jēkabsons, Valters Ščerbinskis, Latgaliešu politiki un politiskās partijas neatkarīgajā Latvijā. Rīga: Jumava, 2006, p. 127.

20 Miķelis Bukšs, Latgaḷu atmūda: idejas un cieñas. Minhene: P/s Latgaḷu izdevnīceiba, 1976, p. 433, 434.

21 Valdis Tēraudkalns, Bībeles tulkošana un izdošana pirmās republikas laikā. $R A$ raksti. Vēsture un filozofija (VII), Rēzekne: Rēzeknes Augstskola, 2007, p. 101.

22 Valerija Seil, Grāmatas Latgales latviešiem. Rīga: Valters un Rapa, 1936, p. 464.

23 Boḷeslavs Brežgo, Latgales zemnieki pēc dzimtbūšanas atcelšanas (1861-1914). Rīga: LVI, 1954, p. 68.

24 Arveds Švābe, Latvijas Vēsture (1800-1914). Stokholma: Daugava, 1962, p. 211.

${ }^{25}$ Ten pat, p. 214.

26 Tadeušs Puisāns, Latgale. Vēsturiskas skices. Toronto, 1988, p. 312.

27 Oto Svenne, Vecā un Jaunā Latgale un vinas ìpatnības. Rīga: Progress, 1923, p. 31.

${ }^{28}$ Latvijas Republikas Satversmes Sapulces stenogrammas, 5. ses., 2848., $2849 \mathrm{sl}$.

${ }^{29}$ Francis Kemps, Latgales likteni, p. 112.

30 Ilga Šuplinska (ed.), Latgolys lingvoteritorialuo vuordneica. Rēzekne: Rēzeknis Augstškola, 2012, p. 305.

31 Ten pat, p. 306.

32 Māra Mellēna, Kapu kopšanas tradīcija. Prieiga per internetą: http://www.kulturaskanons.lv/ lv/1/4/142/

33 Tautas tradīijas. Prieiga per internetą: http:// www.kulturaskanons.lv/lv/1/4/

${ }^{34}$ Laura Uzule, Vita Zelče, Latviešu kapusvētki: identitātes rituāls, p. 202.

35 Ten pat, p. 203. 